\title{
Exposure-plant response of ambient ozone over the tropical Indian region
}

\author{
S. Deb Roy, G. Beig, and Sachin D. Ghude \\ Indian Institute of Tropical Meteorology, 411008 Pune, India \\ Received: 27 November 2008 - Published in Atmos. Chem. Phys. Discuss.: 9 February 2009 \\ Revised: 25 June 2009 - Accepted: 9 July 2009 - Published: 29 July 2009
}

\begin{abstract}
A high resolution regional chemistry-transport model has been used to study the distribution of exposureplant response index (AOT40, Accumulated exposure Over a Threshold of $40 \mathrm{ppb}$, expressed as ppb h) over the Indian geographical region for the year 2003 as case study. The directives on ozone pollution in ambient air provided by United Nations Economic Commission for Europe (UNECE) and World Health Organization (WHO) for vegetation protection (AOT40) have been used to assess the air quality. A substantial temporal and spatial variation in AOT40 values has been observed across the Indian region. Large areas of India show ozone values above the AOT40 threshold limit (3000 ppb h for 3 months). Simulated AOT40 values are found to be substantially higher throughout the year over the most fertile Indo-Gangetic plains than the other regions of India, which can have an adverse effect on plants and vegetation in this region. The observed monthly AOT40 values reported from an Indian station, agree reasonably well with model simulated results. There is an underestimation of AOT40 in the model results during the periods of highest ozone concentration from December to March. We find that the simulated AOT40 target values for protection of vegetation is exceeded even in individual months, especially during November to April. Necessary and effective emission reduction strategies are therefore required to be developed in order to curb the surface level ozone pollution to protect the vegetation from further damage in India whose economy is highly dependent on agricultural sector and may influence the global balance.
\end{abstract}

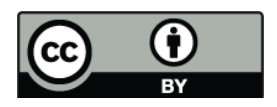

Correspondence to: S. Deb Roy (sompriti@tropmet.res.in)

\section{Introduction}

Near surface ozone is a pollutant of important concern due to its adverse effects on agricultural productivity (Mills et al., 2007) and human health (Avol et al., 1998), and is now a major environmental concern in many regions of the world. Surface ozone is mainly produced through photochemical reactions involving volatile organic compounds and $\mathrm{NO}_{\mathrm{x}}$ in the presence of sunlight, and also acts as a precursor for the highly reactive hydroxyl radical (Logan et al., 1981; Thompson 1992). Epidemiological and toxicological studies indicate that higher concentration of ozone in the boundary layer is harmful to biological health (Avol et al., 1998). The enhanced levels of ozone close to surface also decrease the yield of agricultural crops (Mills et al., 2007). A number of recent studies from selected sites across South Asia have specifically addressed the sensitivity of locally-grown crops to the ozone levels (Agrawal, 2003; Wahid, 2003). Some studies done elsewhere in the world (Tuovinen et al., 2000) have focused on the application of micrometeorological principles to improve the characterisation of vegetation exposure to ozone and described the transition from the exposure index AOT40 to a flux-based approach for estimating ozone risks. Tuovinen et al. (2002) have discussed about the possibility of estimating the value of the AOT40 exposure index from time-averaged (passive sampling) data by using a simplified statistical method even in the absence of continuous data, provided the time-averaged concentration can be measured reliably. Studies like Keller et al. (1999) have shown that assessment based on stomatal ozone flux instead of AOT40, can be used to differentiate ozone risks between regions and years at a national scale. Grünhage et al. (1999) talked about improving the usage of European critical levels for ozone by

Published by Copernicus Publications on behalf of the European Geosciences Union. 
deriving meaningful, reliable and effective dose-response relationships with the application of effective AOT40, which suggests that the estimated crop losses using the effective dose are within the bounds of probability. Few other studies (Fuhrer et al., 1997) provide a critical assessment of the scientific basis of the concepts used to define critical levels for ozone and identifies the key limitations and uncertainties involved. Girgzdiene et al. (2007) have analysed the ground-level ozone data and AOT40 in the rural areas of Lithuania and discussed about the variations and trends in the same. Ghude et al. (2006) have shown that the observed surface ozone levels over Delhi are high enough to exceed "Critical Levels" which are considered to be safe for human health. However, detailed results related to AOT40 for vegetation index based on observational data for the Indian region is sparse. Using surface level measurements from Pune $\left(18.54^{\circ} \mathrm{N}, 73.81^{\circ} \mathrm{E}\right)$, Beig et al. (2008) have recently calculated the AOT40 and shown that ozone levels have surpassed the "Critical Levels" in most parts of the year for vegetation and forest. The monitoring station is located at the northwestern parts of the Pune city which is a well industrialized semi urban city of India at an altitude of around $550 \mathrm{~m}$. Surrounded mostly by hilly areas the site is at a considerable distance from the major traffic junctions and hence defined as semi-urban rather than urban. This is the only work where detailed study about the AOT40 based on observed data has been reported over any Indian station. In the past few decades, India has been undergoing rapid industrial and economic growth with increasing emissions of trace gases and pollutants (Ghude et al., 2008, 2009). Due to all these reasons, the tropospheric ozone level is an issue of concern in the last few decades. Large variabilities even in the vertical distribution of tropospheric ozone over a subtropical site in the IG area, have been reported and analyzed by Gupta et al. (2007). Necessary and effective emission reduction strategies are required to be developed in order to curb the surface level ozone pollution to protect the vegetation from further damage in India whose economy is highly dependent on agricultural sector. Hence, more efforts are needed to understand the spatial and temporal distribution of cumulative exposure indices and threshold exceedances over the whole domain of India. Presently the number of measurement sites having valid and long-term representative measurements of surface ozone in India are quite a few (Pulikesi et al., 2006; Debaje and Kakade, 2008), but the data are scattered and the coverage and time resolution is not sufficient and not very systematic which is essential for a correct and reliable assessment of regional distribution of AOT40. Regional chemical transport models have the potential to fill in this gap. There are few recent modeling studies aimed at describing gridded distribution of monthly AOT40 values over the Indian region (Mittal et al., 2007; Engardt, 2008). The former study was performed using a global emission inventory and the latter one uses an Asian emission inventory (Streets et al., 2003). However, recently a new gridded emission inventory of ozone precursors over the Indian geographical region have been prepared based on micro-level of all activity data (Dalvi et al., 2006; Beig and Brasseur, 2006) which are claimed to be better and found to be quite different than used by earlier modelers. Recently, Roy et al. (2008) have used this new emission inventory in the regional 3-D chemistry transport model for Indian region but the impact of cumulative ozone exposure (AOT40) over the entire Indian region has not been reported so far.

In view of the fact that sufficient measurements of AOT40 are very sparse over the Indian region, and there is a need for estimating the AOT40 over the complete Indian region, we made an attempt in this paper to simulate the ozone cumulative exposure indices and threshold exceedances using the regional chemistry-transport model (REMO-CTM) with new Indian emission inventory for the year 2003 as base case. We have also assessed the simulated results by comparing it with the statistically robust observational data (Beig et al., 2008) available for the suburban site Pune.

\section{Method}

\subsection{Model details}

The model REMO-CTM is a 3-D regional, off-line, eulerian and hydrostatic model. The model has been applied with the ECHAM-4 physics (Jacob et al., 2001; Jacob et al., 2007) in the current study. A terrain following hybrid pressure-sigma coordinate is used in the vertical direction with 20 levels of increasing thickness between surface to $10 \mathrm{hPa}$ pressure level. The horizontal resolution is 0.5 degree on a spherical rotated grid. Further detail of this model is available in Langmann (2000) with references therein. In this study the meteorological parameters generated from the atmospheric component of the on-line model REMO were used to drive the off-line chemical-transport model REMO-CTM. After initializing REMO-CTM once, the model was run in climate mode for the year 2003 using ECMWF analyses at the lateral boundaries which have been updated every $6 \mathrm{~h}$.

The emissions for all the species were obtained from the Reanalysis of the Tropospheric chemical composition $\left(\right.$ RETRO) data which provides $0.5^{\circ} \times 0.5^{\circ}$ emission data set (Olivier et al., 2003) and the recent high-resolution estimates of the new Indian national emission inventory (Roy et al., 2008 and reference therein).

\section{$2.2 \quad$ AOT40}

A number of methodologies have been developed to assess the damaging effects of ozone on vegetation. AOT40 is most widely used exposure plant response index set by the United Nations Economic Commission for Europe (UNECE), United States Environmental Protection Agency (USEPA) and World Meteorological Organization (WMO) 
(World Health Organization (WHO), 2000). All these measurements are based on the concentrations occurring during the sunlit hours of the vegetation seasons. The AOT40 values of $3000 \mathrm{ppb}$ accumulated over a 3 months growing season, and $10000 \mathrm{ppb}$ h over 6 months, correspond to the critical levels (5\% yield loss) for the protection of agricultural crops and forest respectively. It is implied that the critical level for daily AOT40 values is around $33 \mathrm{ppb} h(\sim 3000 / 90)$ which should not be exceeded. The Plant Exceedance Days (PED) are defined as those days when the daily AOT40 value exceeds the critical limit (Beig et al., 2008). The cumulative ozone exposure index (AOT40) is calculated as the sum of differences between the hourly ozone concentrations and $40 \mathrm{ppb}$, for each daylight hour with global radiation greater than or equal to $50 \mathrm{Wm}^{-2}$ during the growing season. In the current study, we have calculated AOT40 for every day by summing the differences between the simulated hourly ozone concentrations at surface (in ppb) and $40 \mathrm{ppb}$, for every hour when the concentration is greater than $40 \mathrm{ppb}$ during the daylight hours between 07:00 a.m.-07:00 p.m. The global radiation over different parts of the Indian geographical region varies depending on the location, month and season of the year. It is difficult to demarcate the different areas of the Indian region based on the distribution of global radiation during the different time periods of the year. Although the global radiation of $50 \mathrm{Wm}^{-2}$ can be observed one hour after sunrise and one hour before sunset (eventually reducing the length of daylight hours by approximately two hours), yet the sunrise and sunset timings vary even in a much shorter distance. Therefore, accounting data as per exact timing and keeping the time duration equal (from statistical consideration) is very complicated issue. We have also assessed monthly modeled AOT40 data at our chosen site Pune where the observed monthly modeled AOT40 data is available for the 07:00 a.m.-07:00 p.m. time window (which is the average sunset and sunrise time at pune). In view of this we have considered uniform time window between 07:00 a.m. and 07:00 p.m. for calculations of AOT40 vales at each grid point over the Indian domain. Since the hourly concentration of ozone in general does not rise immediately close to sunrise and is mostly in the waning phase close to sunset, this addition of one or two hours near the sunrise and sunset time may not significantly effect the AOT40 values over the Indian domain, although our projection may be slightly on the higher side. In our expert opinion, we feel that the uncertainty due to choice of timing interval in the results of AOT40 should not exceed more than $+/-5 \%$. The daily AOT40 values are added when AOT40 over a month period is calculated. In addition to daily AOT40 values, we have also calculated daily 8 -h mean (for 11-18 h) and daily maximum ozone concentration from the simulated results. It is important to note that the critical levels for AOT40 as mentioned in the EU directive are defined as multi-year means so as to compensate for annual variations (Klumpp et al., 2006) but the results presented here are based on the values for a

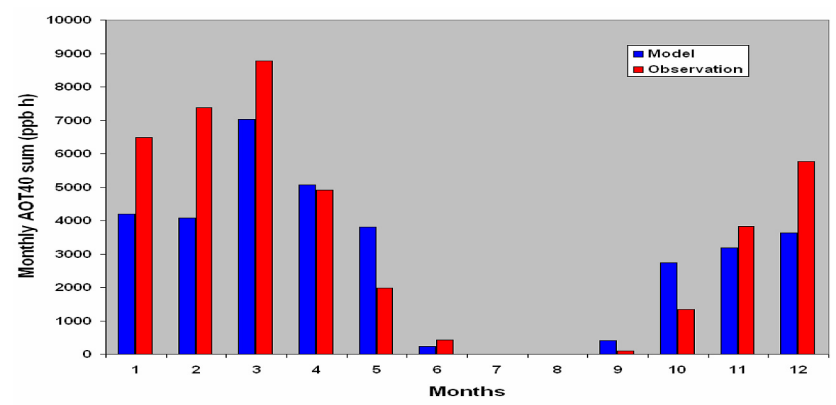

Fig. 1. Comparison of model simulated monthly values of AOT40 with observational data for the year 2003 at Pune.

particular year 2003. It needs to be mentioned here that we have extracted the daily, monthly and 3-monthly AOT40 values from the modeled hourly concentrations of ozone over the Indian region and from the observed hourly ozone data at the receptor site Pune, with the application of codes and scripts following the above mentioned definition.

In the following section, we present the model calculated monthly and daily AOT40 values, daily 8 -h average and the daily maximum ozone levels over the Indian region for the year 2003. We also calculated the model simulated monthly distribution of AOT40 values over the Indian region for the months of May 2003, July 2003 and October 2003. These three months have been chosen as the representative months for the pre-monsoon, monsoon and post-monsoon seasons over India. At the end we provide the modeled 3-monthly distribution of AOT40 over India for the months of November to January and February to April.

\section{Results and discussion}

Figure 1 shows the comparison between monthly AOT40 values calculated from the model and from the point observation at Pune, for the year 2003. It is found that observed monthly AOT40 values lie reasonably in the same range as the modeled values at Pune indicating that our model is capable of reproducing the monthly AOT40 values. It is interesting to note that the UNECE and WHO guideline for the critical limit of AOT40 (3000 ppb hor 3 months) is exceeded even in the individual months. At Pune, elevated monthly AOT40 values were found mostly between November and April both in observed and simulated results, which corresponds to the "Rabi" crop growing season in India. Rabi and Kharif are two types of crop seasons in India, based on the time of sowing and harvesting. The Rabi crop season starts from October/November and harvested in March/April. These are also called winter crops and some examples are Wheat, Barley, Mustard, Sesame, Peas etc. The highest level of monthly AOT40 is seen for the month of March'03 both in observed and model results. Model underestimates AOT40 values during late winter and pre-monsoon season at Pune, although 
the pattern of seasonal variation is similar between the observed and modeled AOT40 values. Over a 6-month period (November-April) the observed AOT40 cumulative ozone exposure exceeded up to $36000 \mathrm{ppb}$ which is almost 3.6 times the critical level set for the protection of forest. While, modeled AOT40 cumulative ozone exposure exceeded up to $27100 \mathrm{ppb}$ h during this period, which is around 2.7 times higher that the critical level for the forest. Beig et al. (2008) reported that the elevated levels of surface ozone and excess of AOT40 values during this period is due to the long range transport of background ozone and its precursors at Pune from the northern plains of Indian sub-continent, which is affluent in ozone and precursor gases (Beig and Ali, 2006). The lowest monthly AOT40 values are generally found during monsoon months. This is due to the inflow of clean marine air mass towards the Indian region brought by the southwesterly winds prevailing during this period and lesser solar insolation (due to cloudy conditions) which leads to lower photochemical production of ozone during this time (Beig et al., 2008). A systematic underestimation in AOT40 ( 35\%) in the model results during the periods of highest ozone concentration (December to March) has been observed. The observational site is located at the northwestern parts of the Pune city $(18.54 \mathrm{~N}, 73.81 \mathrm{E})$ which is a well industrialized semi urban city of India. Most of the industries are situated towards the north eastern and eastern side around 20-25 km away. Since the wind pattern is predominantly northeasterly during the said period, pollutants emitted from these industries can affect the ozone chemistry at the receptor site. Since the model is fed with monthly emissions on a $0.5 \times 0.5$ degree resolution, these local emission effects have not been incorporated as emission inputs to the model. This may have led to the observed systematic underestimation in AOT40 during the periods of highest ozone concentration (December to March). Therefore, there may be an underestimation or overestimation of AOT40 values depending on how much a particular site is affected by local emissions which has not been captured by the model due to coarser resolution. However, we wish to mention here that the ozone distribution over the IGP region, where hotspots are noticed, is largely controlled by the synoptic weather conditions and prevailing dynamics which are very well accounted in the model (Beig and Ali, 2006; Roy et al., 2008) as compared to local emissions and hence uncertainty on these hotspot regions are likely to be much less than Pune region.

Figure $2 \mathrm{a}, \mathrm{b}$ and $\mathrm{c}$ compares the modeled and observed daily AOT40 values (PED), daily 8-h average and daily maximum ozone levels respectively at Pune for the year 2003. The modeled daily AOT40 values, daily 8-h average and daily maximum ozone concentration varies from 0 to $454 \mathrm{ppb}$ h, 25 to $76 \mathrm{ppb}$ and, 31 to $100 \mathrm{ppb}$ respectively. Whereas, the corresponding observed values were found to vary approximately from 0 to $600 \mathrm{ppbh}, 13$ to $107 \mathrm{ppb}$ and 15 to $122 \mathrm{ppb}$ respectively. Daily AOT40 values were found to be almost zero during most of the time in the monsoon

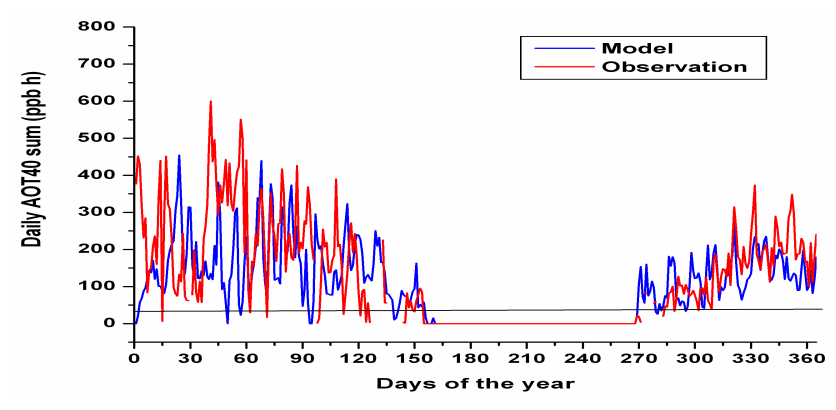

Fig. 2a. Comparison of model calculated daily values of AOT40 with observed data for the year 2003 at Pune. Black horizontal grid line through $33 \mathrm{ppb}$ corresponds to the Plant Exceedance Days (PED).

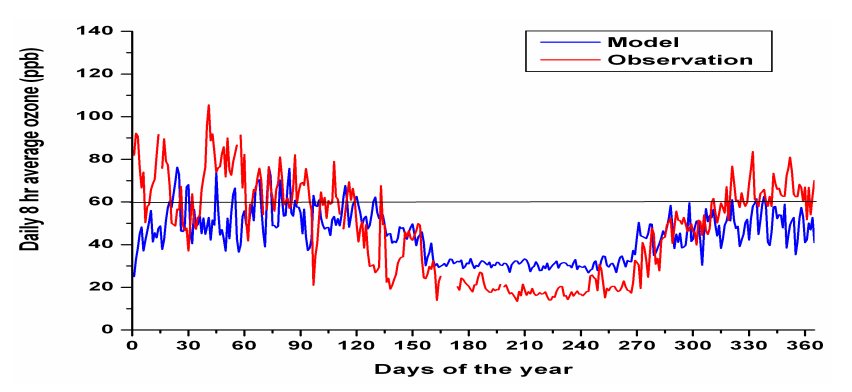

Fig. 2b. Comparison between modeled and observed daily $8 \mathrm{~h}$ average of ozone concentration at Pune for the year 2003. Black horizontal grid line through $60 \mathrm{ppb}$ corresponds to the health protection threshold $(8 \mathrm{~h}>60 \mathrm{ppb})$.

(June-September). Since July to September is mostly growing season for Kharif crops in India like mainly rice in Northern India, low values of AOT40 during this period indicates no threat to crop production. The daily maximum ozone levels and the daily 8-hour average ozone concentration were found to be comparatively lower during the same period. Reduced solar insolation due to frequent cloudy conditions along with the influx of fresh marine air from the oceanic regions towards the Indian land masses leads to lesser photochemical production of ozone during this period. Although the model qualitatively reproduces a similar phenomena, a reasonable quantitative agreement was not obtained in this regard possibly due to the inability of the regional model with $0.5 \times 0.5$ degree resolution, to capture any sudden, localized excess rainfall event which has happened during the monsoon months of the year 2003 as per the rainfall records (IMD-report, 2003) which is discussed in detail by us elsewhere (Roy et al., 2008). Although there are quite a few measurements of ozone reported from India, none of them have reported the AOT40 assessment. Such kind of calculation requires data in much more detailed form than reported by them and we do not have access to any of them in such a detailed manner and hence could perform the AOT40 calculations using observations only for Pune. In our complimentary 


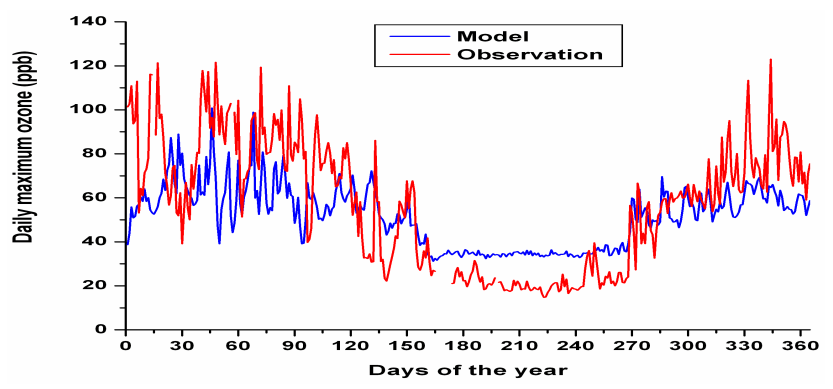

Fig. 2c. Comparison between modeled and observed daily maximum ozone concentrations for the year 2003 at Pune.

JGR paper (Roy et al., 2008) we have shown that the model predicts the geographical distribution of chemical species including ozone concentration (from which AOT40 is derived) over India during the year 2003 to a reasonable extent when compared with observed data. The seasonal cycles of ozone at four receptor sites over the Indian region for the year 2003 has shown good qualitative agreement in comparison with observed data, although there were few quantitative disagreements due to the reasons which have been discussed in detail in (Roy et al., 2008). In addition, the meteorological as well as trace gas data obtained by satellite measurements are compared with model data for whole of the Indian geographical region. We have shown in Roy et al. (2008) that the model has been able to capture the gradient in ozone concentrations between the Indo-Gangetic plains and the remaining parts of India with higher values over the IGP area as has been reported earlier in several observational and modeling studies (Beig and Ali, 2006; Ali et al., 2004). So we are confident that the model performance at Pune with respect to AOT40 can be extrapolated to other sites with different meteorological environment and emission scenario like over the Indo-Gangetic plains where the emission hotspots have been identified, as model is able to capture the distinct features in ozone distribution as discussed above. However, uncertainties due to emission inputs can exist and it is difficult to estimate the uncertainty in the simulated (absolute) concentrations due to the uncertainties in emissions, but is likely to be within 2-5\% (Beig and Brasseur, 2006).

Figure 3 shows the modeled AOT40 distribution at surface level over the Indian sub-continent for the months of May, July and October 2003. It is worth mentioning that even in a single month period (particularly during the month of May) large area of India shows AOT40 values above the $3000 \mathrm{ppb}$ (for 3 months), which is related to $5 \%$ decrease of the yield of many important crops in India. It is also observed that maximum AOT40 values are reached at different times at different regions across India. In all the three months discussed in this study, simulated AOT40 values are found to be substantially higher over the Indo-Gangetic (IG) plains than the other regions of India, which can have an adverse effect on vegetation in this region. However, dur- ing the southwest monsoon season comprising the months from June to September, comparatively reduced AOT40 values are observed over the IG region. The maximum level of AOT40 over the Indo-Gangetic plains of India is found to be $\sim 14000 \mathrm{ppb}$ h during October and $\sim 12000 \mathrm{ppb}$ h during May. While, during July the maximum level of AOT40 is found to be around $6000 \mathrm{ppbh}$ over the IG-region. As can be seen from Fig. 3, the AOT40 values are higher than the critical level in some parts of western India during the month of October. The Kharif crop season lasts from June/July to September/October. These are also known as summer crops. Some examples of these crops are Millets, Paddy, Maize, Pulses, Groundnut, Red Chillies, Cotton, Soyabean, Sugarcane, Turmeric etc. Whereas over some parts of southern India, AOT40 values are higher than the critical level during the month of May. Comparatively low values of AOT40 are seen in the month of July 2003 over most of the geographical region of India except over the IG-region where maximum level of AOT40 is found to be $6500 \mathrm{ppbh}$. The reduced AOT40 values over much of the Indian region during July is mainly due to the south west monsoon circulation which helps in transporting pristine marine air towards the Indian land masses. Also lower solar radiation due to prevailing cloudy situations leads to lesser photochemical production of ozone. While, the higher AOT40 values over the IG-region as compared to the remaining parts of India in all the three months, can be attributed to the fact that this region is affluent in the ozone precursors due to high anthropogenic activity (Ghude et al., 2007; Ghude et al., 2008). The densely populated Indo-Gangetic plains have a substantial level of rural population as well as industries. This makes the IG-region prone to anthropogenic emissions. Included among the emission sources scattered over the entire IG region are coalbased thermal power plants, steel, sugar, and other small and medium industries (several of which use coal as fuel), fossil fuel extraction (coal mining, crude oil production, natural gas production, etc.) and open burning of litter and biofuels used for domestic cooking (Ghude et al., 2008; Beig et al., 2008; Sahu et al., 2008). All these sources lead to observed high ozone values over IG region. But the reasons for high concentration of ozone are both photochemical production as well as prevailing dynamics (Beig and Ali, 2006; Roy et al., 2008) since, this highly populated area (Ghude et al., 2008) is prone to confinement of tracers due to its favorable synoptic conditions and orographic features which favours the photochemical buildup of ozone (Beig et al., 2006; Kulkarni et al., 2009).

In Fig. 4. we provide the 3-monthly AOT40 values over the Indian region for the months from November to January and February to April. The AOT40 values reach as high as $50000 \mathrm{ppbh}$ during the months of November to January towards the eastern side of the Indo-Gangetic plains where the emission intensity of the precursor gases are quite high. In the months of February to April, the highest levels of AOT40 is seen to be around $40000 \mathrm{ppbh}$ in the gangetic 

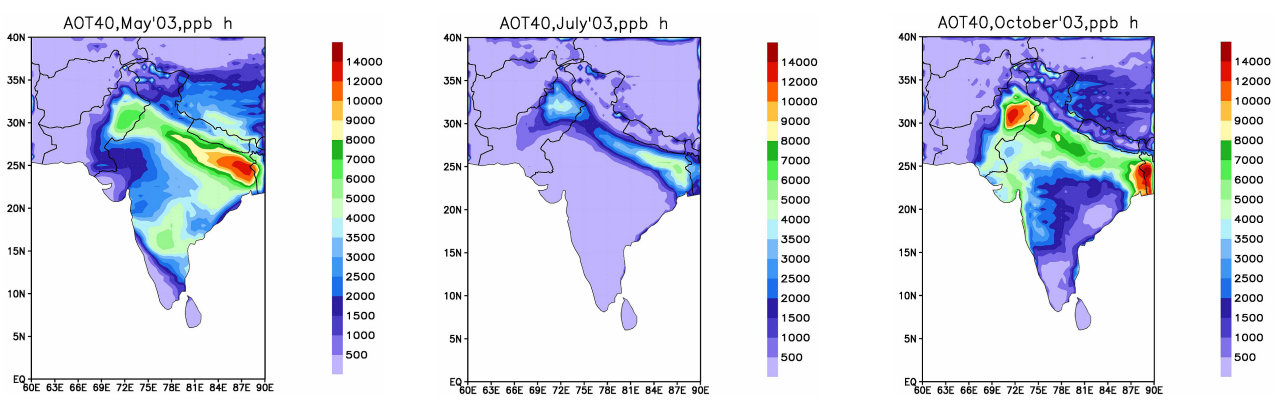

Fig. 3. AOT40 values for the months of May 2003, July 2003 and October 2003 over the Indian region as simulated by REMO-CTM.
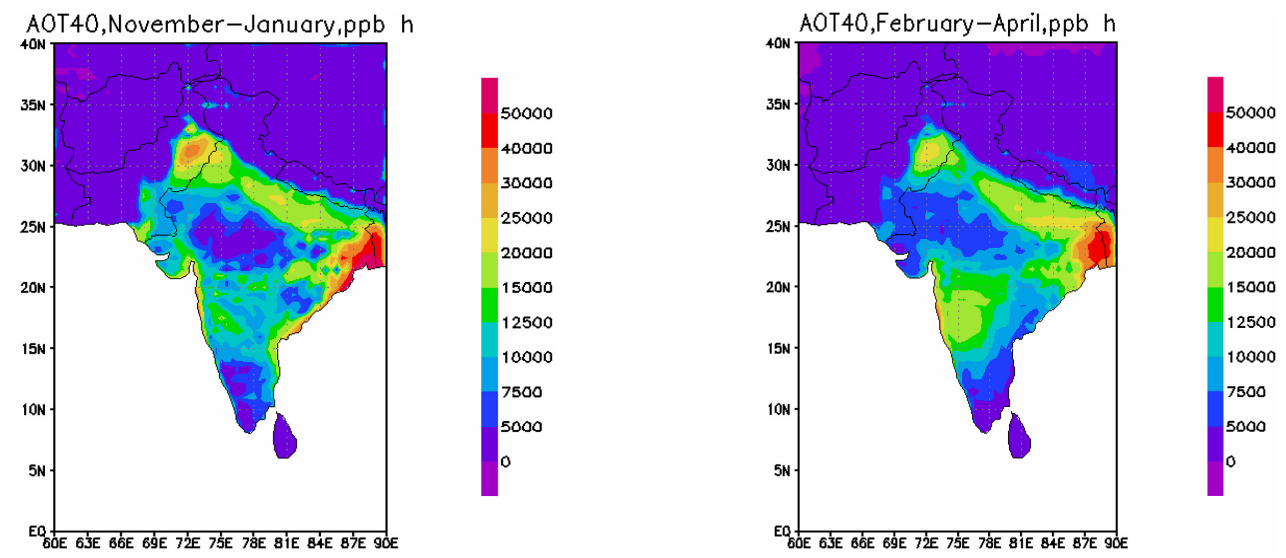

Fig. 4. Modeled 3-monthly AOT40 values for the months of November to January and February to April over the Indian region.

West Bengal. In some parts of south west India where the precursor emissions are on the higher side, elevated levels of AOT40 of around $25000 \mathrm{ppbh}$ are found in both the 3monthly periods. The AOT40 values for the 3 -months period are seen to be comparatively higher over the Indo-Gangetic plains as compared to most of the remaining parts of India. This region is abundant in ozone precursors due to higher prevalence of anthropogenic activities. Also due to its suitable synoptic conditions and orographic features this area tends to confine tracers which enhances the photochemical buildup of ozone. In many parts of Central, Southeastern and extreme Northern India where lower levels of precursor emission prevails, the AOT40 values for 3-month periods are quite low. Overall the AOT40 values for both the 3-monthly periods from November to January and February to April show similar distribution pattern. We have compared our model calculated monthly and 3-monthly distribution of AOT40 values over the Indian region for the year 2003, with those obtained from two other studies (Mittal et. al., 2007; Engardt, 2008). The former study uses a regional model HANK, fed with a global emission inventory to predict the monthly AOT40 values (accumulated during daylight hours from 08:30 a.m.-04:30 p.m., IST) over the Indian region for few months from February 2000 to May 2000. The latter study uses a regional model MATCH with an Asian emission inventory for calculating the 3-monthly AOT40 distribution over India for the year 2000. However, the exact number of daylight hours for which the AOT40 has been calculated is not specifically mentioned in this study. Moreover the colour scales and colour legends along side the AOT40 plots in these studies seems to be poorly resolved. Considering the above mentioned facts, a detailed, point-to-point and sideby-side comparison was not possible in this regard. However, on a crude comparison, we find that the range of our model calculated 3-monthly AOT40 values over the Indian region is close to those predicted by the MATCH model but on the higher side as compared to the results obtained from the model HANK. The pattern of the geographical distribution of our modeled AOT40 values over India for 3-months period appears to be similar with those predicted over the Indian region by the MATCH model. This similarity is not so prominent when we compare our model calculated monthly AOT40 values over the Indian region with the ones obtained from the HANK model. A reason behind this may be that the cellular spatial structure of the distribution pattern is not distinctly visible when a continuous colour scale is used for the gridded plot as has been done for the AOT40 graphs obtained from HANK. 


\section{Summary and conclusions}

In absence of sufficient observational information available about AOT40 over the Indian region, we use the regional chemistry-transport model to estimate cumulative exposure indices in the Indian region for the year 2003. We have also presented a comparison between modeled and measured monthly AOT40 values, daily 8 -h average, daily maximum near surface ozone concentration and daily AOT40 vales at suburban station (Pune). Model is able to reproduce the observed monthly AOT40 values reasonably well. There is an underestimation of AOT40 in the model results during the periods of highest ozone concentration from December to March, since the model has been fed with input emissions on a $0.5 \times 0.5$ degree resolution and is unable to capture the effect of localized emission sources on a subgrid scale during the said period. The exposure-plant response index, is exceeded even in the individual months mostly between November and April at Pune. A substantial temporal and spatial variation in AOT40 values has been observed across the Indian region. Large areas of India show that the directive set by the UNECE and WHO for the critical limit of AOT40 is exceeded even in the individual months as well as in 3months period. It is noticed that maximum AOT40 values are reached at different times at different regions across the Indian region. Comparatively low values of AOT40 are seen in monsoon months over most of the geographical region of India. These values are found to be substantially higher over the Indo-Gangetic plains than the other regions of India. Considering the fact that triple cropping is practiced in the IG-regions, the elevated AOT40 values can have an adverse effect on vegetation in this region.

The results clearly indicate that presently the enhanced concentrations of ozone can have a potential impact on crop yield and forest over the large areas of India. Effective and appropriate regional/local emission control strategies needs to be developed to reduce the incessantly increasing ground level ozone pollution. Regional 3-dimensional photochemical air quality models capable of predicting the evolution of the chemical state of the atmosphere in response to natural or anthropogenic perturbations can play a significant role in defining such mitigation strategies.

Acknowledgements. We are thankful to Mrs.Daniela Jacob, MPIM, Germany and the director of IITM for their encouragement and support in this work.

Edited by: F. J. Dentener

\section{References}

Ali, K., Momin, G. A., Safai, P. D., Chate, D. M., and Rao, P. S. P.: Surface ozone measurements over Himalayan region and Delhi, north India, Ind. J. Radio Space Phys., 33, 391-398, 2004.

Agrawal, M.: Air pollution impact on vegetation in India, in: Air pollution impacts on crops and forests: a global assessment, edited by: Emberson, L. D., Ashmore, M. R., Murray, F., Imperial College Press, London, UK, 165-187, 2003.

Avol, E. L., Navidi, W. C., Rappaport, E. B., and Peters, J. M.: Acute effects of ambient ozone on asthmatic, wheezy, and healthy children, Res. Rep. 82(III), Health Eff. Inst., Boston, Mass., USA, 1-18, 1998.

Beig, G. and Brasseur, G. P.: Influence of anthropogenic emissions on tropospheric ozone and its precursors over the Indian tropical region during a Monsoon, Geophys. Res. Lett., 33, L07808, doi:10.1029/2005GL024949, 2006.

Beig, G. and Ali, K.: Behavior of boundary layer ozone and its precursors over a great alluvial plain of the world: Indo-Gangetic Plains, Geophys. Res. Lett., 33, L24813, doi:10.1029/2006GL028352, 2006.

Beig, G., Ghude, S. D., Polade, S. D., and Tyagi, B.: Threshold exceedances and cumulative ozone exposure indices at tropical suburban site, Geophys. Res. Lett., 35, L02802, doi:10.1029/2007GL031434, 2008.

Dalvi, M., Beig, G., Patil, U., Kaginalkar, A., Sharma, C., and Mitra, A. P.: A GIS based methodology for gridding large scale emission inventories: Application to carbon-monoxide emissions over Indian region, Atmos. Environ., 40, 2995, doi:10.1016/j.atmosenv.2006.01.013, 2006.

Debaje, S. B. and Kakade, A. D.: Surface ozone variability over western Maharashtra, India, J. Haz. Mat., 161(2-3), 686-700, 2008.

Engardt, M.: Modelling near-surface ozone over South Asia, J. Atmos. Chem., 59, 61-80, 2008.

Fuhrer, J., Skärby, L., and Ashmore, M. R.: Critical levels for ozone effects on vegetation in Europe, Environ. Poll., 97(1-2), 91-106, 1997.

Ghude, S. D., Jain, S. L., Arya, B. C., Kulkarni, P. S., Kumar, A., and Ahmed, N.: Temporal and spatial variability of surface ozone at Delhi and Antarctica, Int. J. Climatol., 26, 2054-2062, 2006.

Ghude, S. D., Fadnavis, S., Beig, G., Polade, S. D., and Van der A, R. J.: Detection of surface emission hot spots, trends and seasonal cycle from satellite-retrieved $\mathrm{NO}_{2}$ over India, J. Geophys. Res., 113, D20305, doi:10.1029/2007JD009615, 2008.

Ghude, S. D., Van der A, R. J., Beig, G., Fadnavis, S., and Polade, S. D.: Satellite derived trends in $\mathrm{NO}_{2}$ over the major global hotspot regions during the past decade and their inter-comparison, Environ. Poll., 157(6), 1873-1878, doi:10.1016/j.envpol.2009.01.013, 2009.

Ghude, S. D., Beig, G., and Polade, S.: Tropospheric ozone and precursor gases over Indian subcontinent observed from the space, International symposium on Aerosol-Chemistry-Climate Interaction, PRL Ahmedabad, 20-22 November 2007, 205-206, 2007.

Girgzdiene, R., Bycenkiene, S., and Aloyzas, G.: Variations and trends of ground-level ozone and AOT40 in the rural areas of Lithuania, Environ. Monit. Assess., 127(1-3), 327-335, 2007.

Gupta, S., Lal, S., Venkataramani, S., Rajesh, T. A., and Acharya, Y. B.: Variability in the vertical distribution of ozone over a subtropical site in India during a winter month, J. Atmos. Terr. Phys., 69(13), 1502-1512, 2007.

Grünhage, L., Jäger, H. -J., Haenel, H. -D., Löpmeier, F. -J., and Hanewald, K.: The European critical levels for ozone: improving their usage, Environ. Poll., 105(2), 155-280, 1999.

IMD-report, Indian daily weather report, India Meteorological Department, New Delhi, India, 2003. 
Jacob, D., Andrae, U., Elgered, G., Fortelius, C., Graham, L. P., Jackson, S. D., Karstens, U., Köpken, C., Lindau, R., Podzun, R., Rockel, B., Rubel, F., Sass, B. H., Smith, R. N. D., Van den Hurk, B. J. J. M., and Yang, X.: A comprehensive model intercomparison study investigating the water budget during the PIDCAP period, Meteorol. Atmos. Phys., 77(1-4), 19-43, doi:10.1007/s007030170015, 2001.

Jacob, D., Bärring, L., Christensen, O. B., Christensen, J. H., Castro, M. D., Déqué, M., Giorgi, F., Hagemann, S., Hirschi, M., Jones, R., Kjellström, E., Lenderink, G., Rockel, B., Sánchez, E., Schär, C., Seneviratne, S. I., Somot, S., Ulden, A. V., and Van den Hurk, B.: An inter-comparison of regional climate models for Europe: Design of the experiments and model performance, Clim. Change, 81, 31-52, doi:10.1007/s10584-0069213-4, 2007.

Keller, F., Bassin, S., Ammann, C., and Fuhrer, J.: High-resolution modelling of AOT40 and stomatal ozone uptake in wheat and grassland: A comparison between 2000 and the hot summer of 2003 in Switzerland, Environ. Pollut., 146(3), 671-677, 1999.

Klumpp, A., Ansel, W., Klumpp, G., Calatayud, V., Garrec, J. P., He, S., Peñuelas, J., Ribas, A., Ro-Poulsen, H., Rasmussen, S., Sanz, M. J., and Vergne, P.: Ozone pollution and ozone biomonitoring in European cities. Part I: Ozone concentrations and cumulative exposure indices at urban and suburban sites, Atmos. Environ., 40, 7963-7974, 2006a.

Klumpp, A., Ansel, W., Klumpp, G., Vergne, P., Sifakis, N., Sanz, M.-J., Rasmussen, S., Ro-Poulsen, H., Ribas, A., Peñuelas, J., Kambezidis, H., Shang, H., Garrec, J. P., and Calatayud, V.: Ozone pollution and ozone biomonitoring in European cities. Part II: Ozone-induced plant injury and its relationship with descriptors of ozone pollution, Atmos. Environ., 40, 7437-7448, 2006b.

Kulkarni, P. S., Jain, S. L., Ghude, S. D., Arya, B. C., Dubey, P. K., and Shahnawaz: On some aspects of tropospheric ozone variability over the Indo-Gangetic (IG) basin, India, Int. J. Remote Sens., in press, 2009.

Langmann, B.: Numerical modelling of regional scale transport and photochemistry directly together with meteorological processes, Atmos. Environ., 34, 3585-3598, doi:10.1016/S13522310(00)00114-X, 2000.

Logan, J. A., Prather, M. J., Wofsy, S. C., and McElroy, M. B.: Tropospheric chemistry - A global perspective, J. Geophys. Res., 86, 7210-7254, 1981.
Mills, G., Buse, A., Gimeno, B., Bermejo, V., Holland, M., Emberson, L., and Pleijel, H.: A synthesis of AOT40-based response functions and critical levels of ozone for agricultural and horticultural crops, Atmos. Environ., 41, 2630- 2643, 2007.

Mittal, L. M., Hess, P. G., Jain, S. L., Arya, B. C., and Sharma, C.: Surface ozone in the Indian region, Atmos. Environ., 41, 65726584, doi:10.1016/j.atmosenv.2007.04.035, 2007.

Olivier, J., Peters, J., Granier, C., Petron, G., Müller, J.-F., and Wallens, S.: Present and future surface emissions of atmospheric compounds, POET Rep. 2, Eur. Union, Brussels, Belgium, 2003.

Pulikesia, M., Baskaralingama, P., Rayudub, V. N., Elangoc, D., Ramamurthia V., and Sivanesan, S.: Surface ozone measurements at urban coastal site Chennai, in India, J. Haz. Mat., 137(3), 15541559, 2006.

Roy, S., Beig, G., and Jacob, D.: Seasonal distribution of ozone and its precursors over the tropical Indian region using regional chemistry-transport model, J. Geophys. Res., 113, D21307, doi:10.1029/2007JD009712, 2008.

Sahu, S. K., Beig, G., and Sharma, C.: Decadal growth of black carbon emissions in India, Geophys. Res. Lett., 35, L02807, doi:10.1029/2007GL032333, 2008.

Streets, D. G., Bond, T. C., Carmichael, G. R., Fernandes, S. D., Fu, Q., He, D., Klimont, Z., Nelson, S. M., Tsai, N. Y., Wang, M. Q., Woo, J.-H., and Yarber, K. F.: An inventory of gaseous and primary aerosol emissions in Asia in the year 2000, J. Geophys. Res., 108(D21), 8809, doi:10.1029/2002JD003093, 2003.

Thompson, A. M.: The oxidizing capacity of the Earth's atmosphere: Probable past and future changes, Science, 256, 11571165, 1992.

Tuovinen, J.-P.: Assessing vegetation exposure to ozone: properties of the AOT40 index and modifications by deposition modelling, Environ. Pollut., 109(3), 361-372, 2000.

Tuovinen, J.-P.: Assessing vegetation exposure to ozone: is it possible to estimate AOT40 by passive sampling, Environ. Pollut., 119(2), 203-214, 2002.

Wahid, A.: Air pollution impacts on vegetation in Pakistan, in: Air pollution impacts on crops and forests: a global assessment, edited by: Emberson, L. D., Ashmore, M. R., and Murray, F., Imperial College Press, London, UK, 189-213, 2003.

World Health Organization (WHO): Air Quality Guidelines for Europe, Reg. Publ. Eur. Ser., WHO Reg. Off. Eur., Copenhagen, 2nd ed., 91, 288 pp., 2000. 